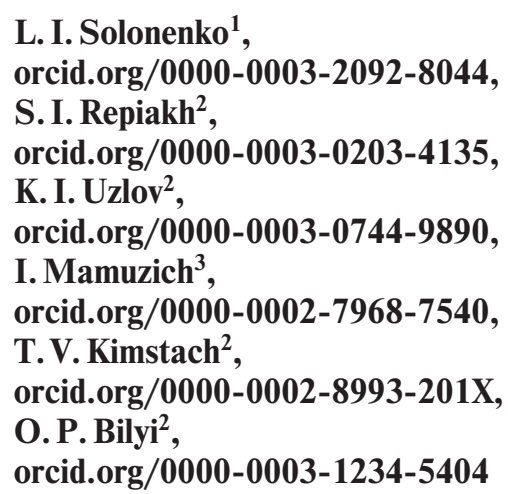

1 - Odesa National Polytechnic University, Odesa, Ukraine 2 - National Metallurgical Academy of Ukraine, Dnipro, Ukraine, e-mail: 123rs@ua.fm

3 - University of Zagreb, Croatian metallurgical society, Zagreb, the Republic of Croatia

\title{
KINETICS OF QUARTZ SAND AND ITS MIXTURES DRYING BY MICROWAVE RADIATION
}

Purpose. Kinetics research and description of drying by microwave radiation mechanism development of quartz sand and its mixes with sodium silicate in limited quantity of water steam medium.

Methodology. Distilled water, sodium silicate solute and quartz sand have been used in this research. Study has been performed on sand samples weighing $200 \mathrm{~g}$. Mixtures drying and structuring have been performed by microwave radiation with power of $700 \mathrm{~W}$ with frequency of $2.45 \mathrm{GHz}$ in air and in saturated water weighing $1 \mathrm{~g}$ steam medium. Accuracy of temperature measurement is $1^{\circ} \mathrm{C}$, mass is $0.02 \mathrm{~g}$. Realized in this investigation drying kinetics has been specified as specimen weight change dependence and moisture evaporation from this mixture rate vs. drying duration. Dependencies have been built on the results of video recording and corresponding chrono-gravimetric measurements data digitalization. Mixtures during heating by microwave radiation temperature changes registration has been performed with an interval of 15-60 s. Samples average heating rate has been estimated by calculation based on results in their temperature change determination during first 2 minutes of heating with microwave radiation.

Findings. For the first time, microwave drying kinetics of quartz sand and its mixtures with sodium silicate in limited water medium (structured by SMS-process) has been studied. For the first time, based on SMS-process material balance, analytical dependence has been developed. This dependence application allows sand-sodium-silicate mixture structured by SMS-process maximum mass to calculate when using sodium silicate solute (silicate module 2.8-3.0) for quartz sand cladding and $1 \mathrm{~g}$ of saturated water steam for mixture structuring. It has been established that when mixtures structuring according to SMS-process water extraction from them takes place in three stages - at $\sim 100,100-108$ and at $125-138{ }^{\circ} \mathrm{C}$. Maximum appropriate heating temperature of sand-sodium-silicate mixture during structuring by SMS-process has been recommended as $\sim 125^{\circ} \mathrm{C}$. Exceeding of specified temperature leads to hydrated water from mixture releasing in steam form and its condensation on colder working surface of model-rod rigging. Resulting condensate leads to mixture restructuring in contact with equipment places and, accordingly, sharp quality deterioration in prepared molds and rods. For manufactured molds and rods quality stabilization, it has been recommended to pre-dry the quartz sand cladded with sodium silicate solute in microwave field for at least 3 minutes before structuring according to SMS-process.

Originality. For the first time, data on drying kinetics has been obtained and quartz sand and its mixtures with sodium silicate in limited water steam medium microwave drying mechanism description has been developed. Influence of number of SMS-process basic parameters on structured quartz sand weight regularities has been established.

Practical value. Research results will be useful in terms of ideas expanding about the processes that accompany granular materials drying, as well as in technologies and equipment for drying and structuring fine-grained dielectric materials and their mixtures development, creating new capillary-porous media, etc. under microwave radiation influence.

Keywords: kinetics, drying, sand, sodium silicate, steam, structuring, microwave radiation

Introduction. Sand-sodium-silicate mixtures (SSSM), hardened by convective drying, by blowing with carbon dioxide $\left(\mathrm{CO}_{2}\right.$-process) or by additions of solid or liquid chemically active technological impurities into them, implementation in foundry is currently limited. In Western Europe's and United States' of America foundries, share of molds and cores made from SSSM does not exceed $9 \%$ [1]. Limited SSSM distribution is caused by number of their significant technological disadvantages, in particular, due to traditional methods of their solidifying using. At the end of the last century this circumstance led to widespread replacement in foundries of sodium silicate solute (SSS) with synthetic resins.

This replacement made it possible to partially solve the problem of molding and core mixtures manufacturability improving. But at the same time, it sharply worsened not only casting production sanitary and hygienic conditions, but also

(C) Solonenko L. I., Repiakh S. I., Uzlov K. I., Mamuzich I., Kimstach T. V., Bilyi O. P., 2021 environment ecological state [2]. This allows to significant problems with production wastes utilization and processing, sand regeneration, cost of used mixtures increasing and, as result, casting expensiveness rising, as it has been reported by A. N. Boldin, S.S. Zhukovsky and A. I. Yakovlev with colleagues (2001, 2010, 2012), S. S. Zhukovsky (2012), and number of other scientists and researchers.

Sand-sodium-silicate mixtures structuring by steam-microwave solidification processing (SMS-process) makes it possible to obtain products, in particular, casting molds and cores, with technological properties level that are difficult or impossible to achieve with today's traditional methods of SSSM solidifying, to reduce the cost of casting production, to prevent pollutions into environment toxic carcinogenic substances, including formaldehyde, phenol, benzene, etc. from casting molds and rods. Whatever it was, SMS process has not yet been used in foundries. This is due to the lack of data on microwave radiation influence in saturated water steam medium on drying and structuring of SSS-cladded quartz sand, on 
this process kinetics and mechanism, its technological capabilities, on mixtures properties, etc. All this not only hinders appropriate equipment development and production, SMSprocess implementation in casting molds and cores manufacturing, but also indicates the relevance of the problem under consideration.

Literature review. Drying and structuring of mixtures kinetics are fundamental knowledge with great practical value. Having such data, drying method has been chosen, mode and energy consumption of drying process have been optimized [3], number of necessary equipment has been calculated [4], amount and types of moisture in materials being dried have been determined [5], etc.

Significant quantity of investigations has been devoted to study of heat and mass transferring processes in capillary-porous bound and unbound, mono- and poly-dispersed media, including fundamental works of A.V.Dumansky (1934), A. F. Lebedev (1936), P. A. Rebinder (1958), M. F. Kazantsev (1960), A. V. Lykov (1968) and number of other scientists and researchers [6, 7]. Reason for significant number of publications and researches in this direction is infinite variety of materials and their properties, conditions, existence forms and materials applications, their combinations, etc. Such research objects include quartz sand cladded with sodium silicate or SSS, and structured by steam-microwave solidification (SMS).

In modern scientific and technical literature, drying kinetics specified as dependence of test material sample moisture (mass) average value changing in time [8], or temperature [9], or specific rate of moisture evaporation from it (specific drying rate is moisture mass evaporated per unit time from $1 \mathrm{~m}^{2}$ surface area of material or product to be dried). Moreover it is not rarely, for quartz sand drying kinetics stages description following classification of water types has been used [10]: free or gravitational (evaporation temperature $-t_{\text {evap. }}=100{ }^{\circ} \mathrm{C}$ ), hygroscopic or adsorption $\left(t_{\text {evap. }}=103-108^{\circ} \mathrm{C}\right)$, crystallization or hydration $\left(t_{\text {evap }}<300^{\circ} \mathrm{C}\right)$, constitutional $\left(t_{\text {evap }}=300-1000^{\circ} \mathrm{C}\right)$. According to M. F. Kazantsev (1960) classification, moisture in capillary-porous bodies could be divided into physical-mechanical (free) and physical-chemical (bound). Free water includes moisture in coarse pores, in intergranular junctions (cuffs) and micro pores, bound moisture - poly-molecular and molecular adsorption moisture.

In capillary-porous bodies drying processing, researchers usually distinguish three periods [11]. First period has been characterized by drying body temperature rising and moisture from its surface evaporation rate increasing. First period lasts until dried body reaches temperature of $100{ }^{\circ} \mathrm{C}$. Second period has been characterized by drying rate and dried body temperature invariability, achieved in first period. Third period is stage of drying rate decreasing (down to zero) and body temperature monotonous increasing. Mass transferring intensity during this period is limited by both external and internal moisture diffusion in body and heat transfer becomes dependent on both conditions of external and internal heat transfer.

Main difference between microwave heating and other methods is vectors of moisture and heat transfer in capillaryporous bodies coincidence (from inside to surface), as well as heating selectivity and dependence of its level on each mixture components dielectric constants values. These features lead to the fact that drying by microwave radiation rate is much higher than drying by convection or radiation, which has been noted in numerous works, including Zh. M. Kurbanov's with coauthors (2015) results. At the same time, Zh. M. Kurbanov notes that with microwave radiation power increasing, drying rate increases, and each value of microwave radiation power corresponds to dried material certain effective mass. In publication [12], authors confirm microwave drying high efficiency on the basis that values spreading for moisture content in dispersed soils determining during drying in a microwave oven, as a rule, is not higher than during convection drying.
Investigating of SSSM properties, prepared by mixing quartz sand and SSS, Wang J. with collaborators (2009) established not only their high strength, but also their high tendency of moisture from air absorption. At the same time, influence of sodium silicate solute content in the range from 1 to $2 \%$ in the sand and microwave power in the range from 700 to $2000 \mathrm{~W}$ on solidified freshly prepared mixture strength is ambiguous. But certain directly proportional relationship between solidified SSSM strength and microwave radiation power has been taken place.

Among the components of SSSM solidified by SMS process are water in liquid and vapor state, quartz sand, sodium silicate (SS) and its aqueous solution. Quartz sand dielectric permeability is 4.6 units and SS - 17.2 units [13], and these materials specified indicators practically do not change with temperature changing. At the same time, numerous researchers have established that water dielectric constant $(\varepsilon)$ decreases both with temperature increasing and with its layer thickness decreasing on substrate. In particular, this follows from Yu. V. Mulev and S. N. Smirnov (1992) formula

$$
\varepsilon=24.174 \frac{N \cdot \rho \cdot \mu^{2}}{M \cdot k \cdot T}-7.180,
$$

where $N$ - Avogadro constant; $\rho$ - water (steam) specific density at temperature $\mathrm{T} ; \mu-$ water molecule dipole moment; $M$ - water molecular mass; $k$ - Boltzmann constant; $T$ - temperature.

Assuming: $N=6.02209 \cdot 10^{23} \mathrm{~mol}^{-1} ; \mu=0.0473 \cdot 10^{-23} ; M=$ $=0.018 \mathrm{~kg}$ and $k=1.38066 \cdot 10^{-23}$. Water specific density in temperature range from 283 to $373 \mathrm{~K}$ can be calculated using equation

$$
\begin{aligned}
\rho=327.6447399 & +5.9221562 \cdot T-0.0162779 \cdot T^{2}+ \\
& +0.0000132 \cdot T^{3} .
\end{aligned}
$$

Then it occurs that at $20{ }^{\circ} \mathrm{C}$ value $\varepsilon=81$, and at $100{ }^{\circ} \mathrm{C}-$ $\varepsilon=51$.

Transforming into vaporous state, water dielectric constant becomes close to 1 . That is, microwave radiation practically does not heat water steam. This should be taken into account in microwave radiation drying processes.

In cases when dried mixture contains easy-melting or water-soluble binding substance, such mixture drying process is also accompanied by structuring. Structuring mixtures mechanisms with different nature binder materials are characterized by number of fundamental differences. In particular, clays solidify by coagulation mechanism, when small water content turns clay into viscous, highly concentrated colloidal mass with high adhesion properties to sand, and after water removing - into stone. Gypsum and cement solidification, for example, realizes as result of their mixing water influence, which is one of hydration reactions components and participates in certain form new crystalline hydrates formation [14]. Phosphate binders solidify according to coagulation - poly-condensation mechanism [15], thermosetting resins - according to poly-condensation mechanism [16], etc. At the same time, SSS could be solidified by poly-condensation mechanism with new solid astringent chemical compounds formation in it or by coagulation mechanism as dehydration result (as dehydration result or certain organic compounds using), its $\mathrm{pH}$ value decreasing, silicate modulus increasing, etc. [17].

At low rate of external heating, according to I. V. Ryzhkov, V. S. Tolstoy (1975), V. I. Korneev, V. V. Danilov (1996), as well as [18], sodium silicate solute solidifies at $100{ }^{\circ} \mathrm{C}$ and contains residual water $17-35 \%$ (by weight). Retained in SSS water is hydrated and removed at higher temperature. In this case, the mass rate of hydrated water removing is lower than that of free water. Complete SS dehydration (last $3-4 \%$ of water removing) occurs when it has been heated to $\sim 600{ }^{\circ} \mathrm{C}$, according to V. I. Korneev, V. V. Danilov (1996). Moreover, SSS heating intensity increasing leads not only to its dehydration, but also to 
foaming. According to B. I. Petrakov, A. V. Lopatkin (1993), V. I. Korneev, V.V.Danilov (1996), foaming reason - is steam pressure in SSS deep layers excess of atmospheric pressure value or moisture content significant gradient along particle depth or solidified SSS layer. At the same time, SSS drying with silicate modulus value of $2.8-3.0$ by microwave radiation heating to $\sim 150{ }^{\circ} \mathrm{C}$ with magnetron power of $700 \mathrm{~W}$ and frequency of $2.45 \mathrm{GHz}$ provides water content in SSS reducing to less than $0.1 \%$ (by weight) [18]. Authors [19], using microwave radiation for drying gypsum molds, note that water mass decreasing in gypsum specimens during their drying can be described by exponential dependence. Moreover, microwave radiation power increasing intensifies drying process. At the same time, high-power microwave radiation using leads to gypsum specimen destruction or significantly reduces its strength properties.

Based on researches results of A. V. Dumansky (1934), P.A. Rebinder (1958), M. F. Kazantsev (1960), A. V. Lykov (1968), V. I. Korneev, V. V. Danilov (1996) and number of other scientists and researchers, for processes that take place during drying of sand and its mixtures with SSS (sodium silicate (SS)) description, accepted the following initial states and state changes under microwave radiation action.

Saturated water steam (SWS) - is a gaseous substance, which, according to experimental conditions of this work, has been generated from $1 \mathrm{~g}$ of water (water charge - WC) in microwave radiation field. Since SWS dielectric permeability is close to unit and SWS has free exit from mixture into atmosphere, it is not heats by microwave radiation and keeps constant temperature of $100{ }^{\circ} \mathrm{C}$.

When using WC, water in mixture capillaries has been formed as a result of SWS condensation on capillaries walls (condensate). Condensation process continues until mixture temperature reaches $100{ }^{\circ} \mathrm{C}$. Condensate in capillary-porous body is hygroscopic moisture, which settles (adsorbs) on capillaries surfaces in continuous layer form (film). According to R. I. Gomboev and I. G. Simakov (1999), regardless of adsorption layer of water temperature, up to 20 monolayers of water molecules its dielectric permeability is less than water dielectric permeability in large volume and is $\varepsilon \approx 5$. Apparently, this circumstance sharply reduces condensate thermal activity during mixture (sand) heating, but allows it to participate in hydration and creation of SS solutions processes. That is, if sand grains surfaces has been cladded with SS, then condensate can be partially or completely absorbed by them. Joining SS molecular structures, absorbed water becomes its part - hydrated (chemically bound) water. With an excess amount, condensate with SS forms SS - sodiumsilicate-solute aqueous solutions of various specific gravity. At other equal conditions free water evaporation from WC, SSS and $\mathrm{SS}$ begins at the moment when water steam partial pressure in air becomes less than moisture in mixture partial pressure. At the difference between these partial pressures decreasing moisture from mixture evaporation rate decreases and stops generally when this difference in partial pressures becomes zero.

Quartz sand - is solid granular body that heats up relatively slowly in microwave field and practically does not absorb water. Condensate continuous layer formation on sand particles and contact points between neighboring sand grains presence leads to capillary forces appearance in analyzed system of bodies. Capillary forces activate condensate layers film movement on sand grains surfaces. Result of such targeted water movement to neighboring sand grains contact places is water bridges between sand grains in cuffs form appearance.

Sodium silicate solute (SSS) - is sodium silicate aqueous solution. In terms of chemical composition, SSS is colloidal hydrated sodium silicate aggregates mixture $\beta-\mathrm{Na}_{2} \mathrm{O} \cdot n \mathrm{SiO}_{2}$ and $\gamma-\mathrm{Na}_{2} \mathrm{O} \cdot n \mathrm{SiO}_{2}$ in water. In initial state $\mathrm{SSS}-$ is liquid which with water content decreasing in it transits into viscous state. With $20-30 \%$ by weight water content SSS solidifies and with further water content decreasing it turns into hydrated and then into dehydrated SS.
Sodium silicate $(\mathrm{SS})$ - is solid substance. As result of quartz sand cladding with a thin layer, covers sand particles surface. Depending on drying conditions SS in cladding layer can be hydrated or dehydrated. Sodium silicate forms as a result of SSS dehydration. That is, if during cladding sand has been mixed with SSS and dried in air at $22-32^{\circ} \mathrm{C}$, then SS will contain about $20-30 \%$ (by weight) of hydrated water. If the cladded sand has been additionally dried with microwave radiation, water content in SS will decrease to less than $0.1 \%$ by weight. Contacting with water partially or completely dehydrated SS absorbs it, incorporating water molecules into own structure. After saturation hydrated SS passes into solution with water excess. Such SS aqueous solution, as well as condensate in sand, forms cuffs between grains. From these cuffs during continuous heating free water primary removes at $100{ }^{\circ} \mathrm{C}$ and then, reaching higher temperature, hydrated water releases. As a result SS in cuffs turns into solid substance with high adhesion to quartz sand and SSSM structures.

Methods and materials. Distilled water, SSS with silicate modulus of $2.8-3.0$ and specific density of $1.44 \mathrm{~g} / \mathrm{cm}^{3}$, quartz sand with average particle size of $0.23 \mathrm{~mm}$ and an impurity content less than $0.2 \%$ by weight have been used in this work. Studies have been carried out on samples of sand and its mixtures weighing $200 \mathrm{~g}$. Weighed portions consisted of both pure sand and quartz sand with $0.5 \%$ (by weight over $100 \%$ quartz sand) water mixture, quartz sand with $4.5 \%$ (over $100 \%$ quartz sand) SSS and quartz sand cladded with SS. Mixtures drying and structuring have been carried out by microwave radiation heating with power of $700 \mathrm{~W}$ at frequency of $2.45 \mathrm{GHz}$ in air and in SWS medium with mass of $1 \mathrm{~g}$.

Sand and its mixtures weighed portions temperature has been determined by electronic potentiometer with an accuracy of $1{ }^{\circ} \mathrm{C}$, equipped with contact $\mathrm{NiCr}-\mathrm{CuNi}$ thermocouple with electrodes diameter of $0.2 \mathrm{~mm}$. Weighed mixtures temperature structured by SMS-process has been measured in their central parts every $15-60 \mathrm{~s}$ of heating by microwave radiation. Mass determination has been realized on electronic balance with an accuracy of $0.02 \mathrm{~g}$.

Kinetic curves have been plotted according to data obtained on device which scheme has been shown in Fig. 1.

During these studies carrying out sand/mixture sample 6 weighing $200 \mathrm{~g}$ in cardboard container (cup) has been placed in device working chamber 1 . If necessary, WC has been placed in the bottom of container. For testing aim cardboard container with weighed amount of sand/mixture 6 has been suspended on thread 7 in equipment working chamber 3 . Thread 7 has been fixed on electronic balance 4 , which has been placed on support 5 above device 1 . When device 1 has been turned on microwave radiation entered its working chamber through waveguide window 2 . Changes in sample weight, during its processing with microwave radiation, have been fixed by video recording from light display of electronic balance. Then, using these results, kinetic (chrono-gravimetric)

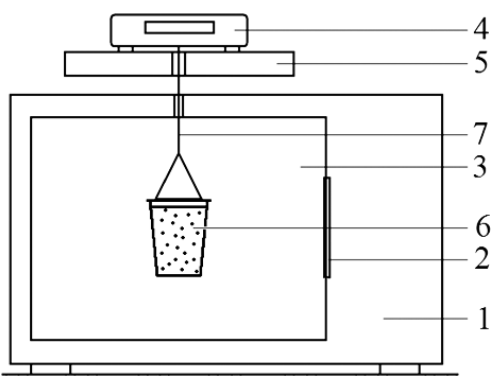

Fig. 1. Scheme of device for sand sample mass changing determination during drying by microwave radiation:

1 -device for microwave radiation generating; 2 - waveguide window into working chamber of device; 3 - working chamber of device; 4 - electronic balances; 5 - balances support; 6 - sand (mixture) weighed portions in cardboard container; 7 - thread 
curves have been plotted. Samples average heating rate has been determined by calculation, using measured results of their temperature changing for the first 2 min of heating by microwave radiation.

Results. Quartz sand with $0.5 \%$ water mixture drying. Quartz sand with water mixture sample drying kinetics (water content in mixture is $0.5 \%$ by mass over $100 \%$ of sand), as well as dry quartz sand sample with WC (mass of $0.5 \%$ over $100 \%$ of dry quartz mass sand) in the form of corresponding changes in samples weight vs. their treatment with microwave radiation duration dependencies, and changes in the rate of water evaporation from sample open surface kinetics have been shown in Fig. 2.

Dependence 1 in Fig. 2 course analysis shows that mixture of pure sand with water under microwave radiation action drying process has been characterized by steady decreasing in mass over time. At the same time, sample mass change kinetics and its drying rate are similar to the known kinetic curves for capillary-porous bodies convective or radiation drying, where three periods are distinguished ( Fig. 2).

Period $\boldsymbol{A}-\boldsymbol{B}$. It has been characterized by initial sample weight over time invariability. At this time period, water in sample has been heated under microwave radiation action, but has not yet evaporated from its open surface. Water (moisture) in sample evaporation begins at the moment when moisture steam partial pressure in sand capillaries exceeds steam partial pressure in air - surrounding gaseous medium. Since sample heating under microwave radiation starts from inside, resulting SWS moves through sand capillary channels from places of its origin to sample open surface. As it moves through capillary channels SWS partially condenses on their walls. Subsequently water (condensate), formed from steam, heats up again, evaporates and its movement continues in SWS form to sample open surface.

Period $\boldsymbol{B}-\boldsymbol{C}$. It has been characterized by sample weight decreasing beginning (point $B$ on dependence 1 in Fig. 2), which has been associated with SWS its open surface achievement and steam escape into environment. In this case, at point $C$, water evaporation rate from sample reaches its maximum value.

Period $\boldsymbol{C}-\boldsymbol{F}$. Sample weight changing dependence during $C-F$ period is smoothly descending curve from point $C$ - time of moisture from sample open surface evaporation maximum rate to point $F$ - time of moisture evaporation from sample completion. That is, at time moment corresponding to point $C$, decreasing in steam partial pressures in sand and it surrounding air difference begins. At the moment of time corresponding to point $F$ ( $F-$ is point of equilibrium moisture), difference in sample capillaries moisture and in surrounding it air partial pressures becomes zero. Accordingly, at this moment in time, water evaporation from sample stops. In this case, part of the steam (less than $0.1 \%$ by weight) at the test end remains in sand capillary channels.
From curve 1 in Fig. 2 course analysis it follows that quartz sand with water mixture under microwave radiation action drying kinetics is practically similar to wet sand by other methods drying kinetics, which has been described in works of M. F. Kazantsev (1960), A. V. Lykov (1968), V. I. Mushtaev, V. M. Ulyanov, A. S. Timonin (1984) and number of other authors. That is, sand with moisture uniformly distributed in it drying by microwave radiation has not been accompanied by any previously unknown phenomenon and processes that are not typical for wet sand drying by other methods of heat transferring - convection, radiation or thermal conductivity.

Quartz sand drying at WC presence in it. Quartz sand drying kinetics, through which SWS passes, formed as result of water evaporation from WC, has been described by dependence 2 , shown in Fig. 2. Unlike dependence 1, on dependence 2 (Fig. 2) 5 following periods can be distinguished.

Period $\boldsymbol{A}-\boldsymbol{B}$. During period $A-B$ of dependence 2, processes similar to dependence 1 processes of period $A-B$ have been taken place. Significant difference between WC water evaporation processes from water evaporation initially evenly distributed over sand entire volume is time length of SWS sand sample open surface reaching.

In case of WC using, this period is slightly longer than in previous sample. This is due to the fact that under microwave radiation exposition, wet sand begins to heat up at high speed almost simultaneously throughout entire volume. At the same time, when using WC, dry sand in sample under microwave radiation, having dielectric permeability $11-17$ times less than water, heats up at much lower rate than wet sand. This leads to the fact that SWS, contacting in capillary channels with colder sand grains, intensively, but only partially, condenses on them with subsequent condensate evaporation, after time interval $\tau_{\mathrm{AD}}$. SWS condensation on relatively sand cold grains accelerates their heating process and cools the condensate to lower temperatures. As a result, SWS evaporation from wet quartz sand open surface begins after 6-7 s (dependence 1 in Fig. 2) from the moment of microwave radiation begins to affect it, and in the case of WC using - only after $\sim 64 \mathrm{~s}$ (dependence 2 in Fig. 2).

Period $\boldsymbol{B}-\boldsymbol{C}$. This period has been characterized by sample weight sharp decreasing. Such mass decreasing nature has been explained by the fact that WC water mass exceeds condensate mass which can form in sand capillary channels during specific time. That is, in accordance with dependence 2 course in Fig. 2, if WC mass were $0.4 \%$ of sand mass, then in initial period of heating by microwave radiation all the steam formed from WC would be on sand grains in condensate form. From this it follows that sample weight decreasing by $0.1 \%$ during $B-C$ period - is steam that did not have time to condense on sand grains during its movement through capillary channels and if WC sample had a smaller mass of not $0.5 \%$, but $0.4 \%$ of sand mass, then period $B-C$ would be absent on kinetic curve.

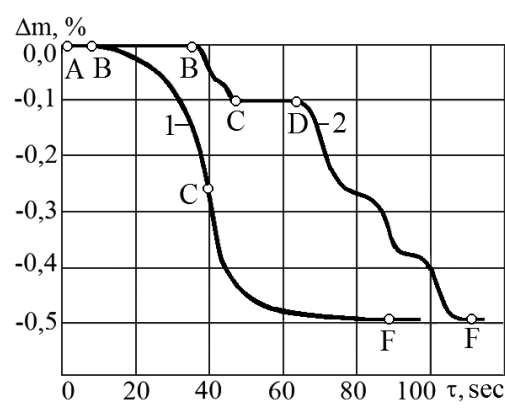

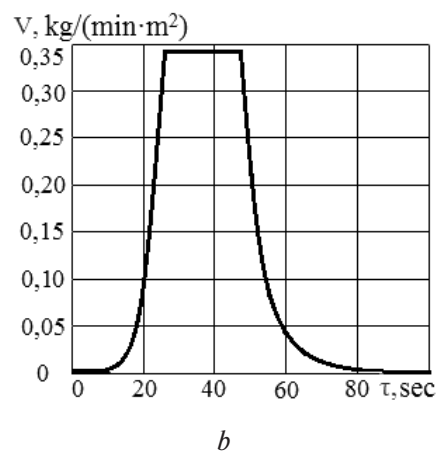

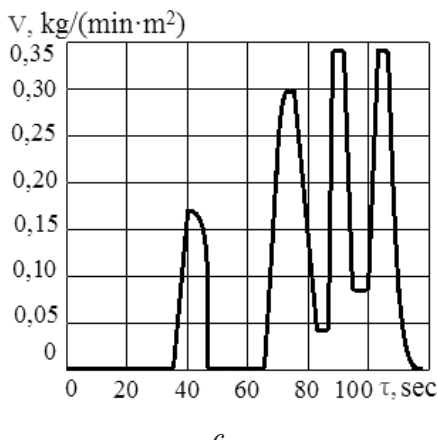

Fig. 2. Changes in mixture of $200 \mathrm{~g}$ of pure sand with $1 \mathrm{~g}$ of water mass (sample 1) and $200 \mathrm{~g}$ of pure sand with $1 \mathrm{~g}$ of WC (sample 2), placed in the bottom part of the sample, dependences on duration of its treatment with microwave radiation (a); kinetics of change in the rate of evaporation of water from the open surface of sample 1 (b) and sample 2 (c) 
Period $C-D$. This period, in fact, is $A-B$ period continuation and has been characterized by absence of "excess" steam into the air releasing and condensate heating to $\sim 100{ }^{\circ} \mathrm{C}$. From the time moment indicated by point $\mathrm{D}$ on dependence, the process of condensate evaporation and SWS exit through sand sample open surface into environment renewing. It follows from this that in $B-C$ period absence, $A-B$ period should have had a real duration

$$
\tau_{A D}=\tau_{A B}-\tau_{B C}+\tau_{C D},
$$

where $\tau_{A D}, \tau_{A B}, \tau_{B C}, \tau_{C D}-$ periods $A-D, A-B, B-C$ and $C-D$ duration, corresponding.

Period $\boldsymbol{D}-\boldsymbol{F}$. $D-F$ period on curve 2 is condensate evaporation from sand time, which has been characterized by variability in mass decreasing rate. This has been explained by number of factors in this period junction, including condensate in sample capillaries cyclic appearance and evaporation, directing of SWS movement along the capillaries from WC to sample open surface, and sample throughout its volume temperature field inhomogeneity. At point $F$, for reason indicated above, water evaporation from sample finishes.

Quarts sand mixture with $4.5 \%$ SSS drying._Quartz sand with $4.5 \%$ (over $100 \%$ of sand) unsolidified SSS mixture mass change dependence, as well as water from sample open surface evaporation rate change kinetics have been shown in Fig. 3.

Difference between this mixture and mixtures described above is presence in it of evenly distributed over sample volume SS - SSS aqueous solution. In this case, one part of SSS covers sand grains surfaces with thin film, and other part, moving under capillary forces action, forms cuffs around contact points of neighboring sand grains. Complex nature of this sample mass and drying rate kinetics changing evidences about moisture movement mechanism repeated changing in it. As it is known, with rapid heating, SSS is foaming and during drying can form foam structures with varying stability degrees. This makes certain changes in such mixtures drying kinetics.

From dependence in Fig. 3 course analysis it follows that water evaporation from this mixture duration is similar to water evaporation from its mixture with pure sand duration (dependence 1 in Fig. 2), and evaporation kinetics is similar to WC evaporation from pure sand (dependence 2 in Fig. 2).

Period $\boldsymbol{A}-\boldsymbol{B}$. This period lasts first 6-7 s from microwave radiation heating beginning. During this time, mixture heats to $100{ }^{\circ} \mathrm{C}$ only in separate (mainly internal) sample parts. Therefore, steam generated from free water, which is present in SSS, moves to sample open surface and only partially condenses on relatively cold surfaces of its capillaries.

Period $\boldsymbol{B}-\boldsymbol{C}$. Period $B-C$ has been characterized by the fact that at point $C$ free water evaporation process has been completed, and SWS non-condensed part, reaching sample open surface, goes beyond its body, reducing its mass.

Period $\boldsymbol{C}-\boldsymbol{G}$. During $C-G$ period, apparently, secondary hydration with condensate of partially dehydrated SSS has been taken place, resulting solution temperature rises to 103-
$108{ }^{\circ} \mathrm{C}$ and its foaming. However, resulting steam remains in SS bubbles. For this reason, sample weight does not decrease during this time period.

Period $\boldsymbol{G}-\boldsymbol{L}$. Linear nature of sample weight decreasing, obviously, at this heating period, is due to further sample temperature increasing, to new foam bubbles appearance, volume increasing and previously formed foam bubbles destruction.

Period $\boldsymbol{L}-\boldsymbol{E}$. Steady monotonic foam bubbles size increasing under the action of steam pressure in them in capillary limited space increasing leads to their destruction. This shifts $L-E$ segment initial section into almost perpendicular position corresponding to heating time axis in Fig. 3. That is, this period has been characterized by explosive releasing (emission) of steam from the sample and, accordingly, almost its mass immediate decreasing.

Period $\boldsymbol{E}-\boldsymbol{F}$. Period $E-F$ has been characterized by sample weight monotonic decreasing up to $77 \mathrm{~s}$. Apparently, during this heating time period, SSS foamed structures completely destroys under the action of steam pressure increasing in their bubbles, as a result of SS elasticity losing. By the end of this period, SS becomes solid and dehydrated, and remains of formed SWS go beyond the sample frames.

Quartz sand drying, cladded with $3.0 \%$ SSS, dried in air with WC using. Quartz sand cladded with $3 \%$ SSS and contained $\sim 20 \%$ hydrated water after its drying in air relative mass changing, as well as water evaporation from sample open surface rate changing kinetics have been shown in Fig. 4.

Period $\boldsymbol{A}-\boldsymbol{B}$. During this time period SWS with mass of $1 \mathrm{~g}$ for $38 \mathrm{~s}$ continuously and evenly enters the mixture and by the end of this period reaches its open surface. In movement process SWS partially condenses on capillaries surfaces of mixture, forming cuffs between neighbors sand grains. Water from condensate partially absorbs by SS, as a result forms SS aqueous solution and, being reheated by microwave radiation, partially returns to SWS state, and also participates in the beginning of hydrated SS foaming process.

Period $\boldsymbol{B}-\boldsymbol{C}$. This period has been characterized by uniform rate of steam releasing from the sample. Sample weight decreasing during period $B-C$ is probably due to foam bubbles in mixture capillaries limited space appearance and destruction and part of SWS departure outside the sample.

Period $\boldsymbol{C}-\boldsymbol{D}$. During this period has been taken place foam structure destruction in sample composition completing, hydrated SS cuffs appearance between neighboring sand grains and chemically weakly bound hydrate water explosive removing from them. This water turns into SWS and partially leaves the sample.

Period $\boldsymbol{D}-\boldsymbol{E}$. This period has been characterized by steam releasing from the sample completion and its temperature to $125-127^{\circ} \mathrm{C}$ increasing.

Period $\boldsymbol{E}-\boldsymbol{F}$. During period $E-F$, when residual hydrated water with a strong chemical bond with SS removes from sample, its weight decreases monotonously (from 80 to $110 \mathrm{~s}$ ). In this case, SS already predominantly has been located in cuffs.
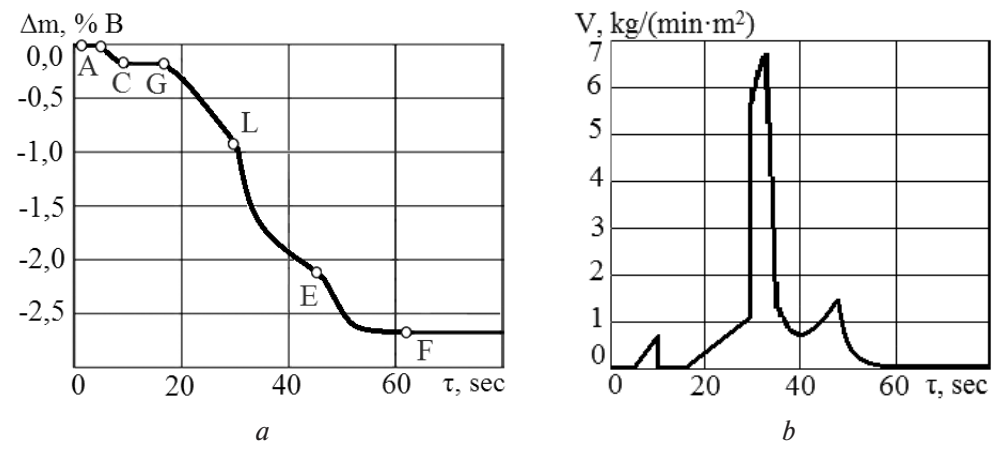

Fig. 3. Quartz sand with $4.5 \%$ (over $100 \%$ of sand) SSS mixture (sample 3) mass changing dependence vs. its treatment with microwave radiation duration (a); water from open surface of sample 3 evaporation rate kinetics changing $(b)$ 

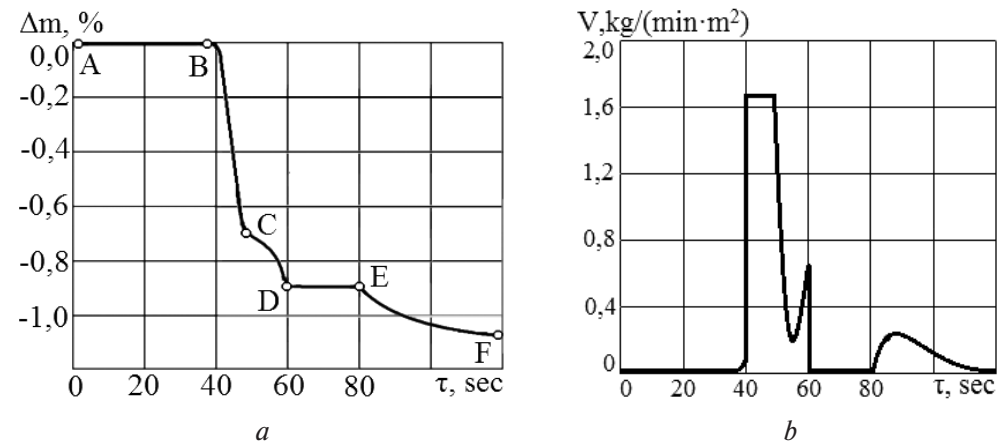

Fig. 4. Quartz sand cladded with $3 \%$ SSS (contained hydrated water $20 \%$ ) sample 4 relative mass changing vs. duration of its drying in air (a), evaporation from sample 4 open surface kinetics changing rate (b)

Removing water from the cuffs provokes slight SS foaming and subsequent formed foam structures destruction. Passing into vaporous state, water in SWS form leaves sample frames.

Quartz sand drying, cladded with $3.0 \%$ SSS, dried by microwave radiation using $W C$. Dependences of quartz sand cladded with $3 \%$ SSS and contained less than $0.1 \%$ hydrated water after its microwave radiation drying relative mass changing vs. microwave radiation treatment with $0.5 \% \mathrm{WC}$, as well as water evaporation from sample open surface changing kinetics rate have been shown in Fig. 5.

Based on dependencies in Fig. 5 courses cladded quartz sand drying and structuring can be distinguished by characteristic time periods, which singular points on $\Delta m=f(\tau)$ dependence have been indicated by corresponding letters.

Period $\boldsymbol{A}-\boldsymbol{B}$. During this time period SWS with mass of $1 \mathrm{~g}$ for $28 \mathrm{~s}$ continuously and uniformly enters the mixture and by the end of this period reaches its open surface. During moving process SWS partially condenses on mixture capillaries surfaces, forming cuffs between neighboring sand grains. Water from condensate partially absorbs by SS forming SS solution and, being reheated by microwave radiation, partially returns to SWS state, and partially participates in hydrated SS foaming.

Period $\boldsymbol{B}-\boldsymbol{C}$. Except for SWS influx into the mixture from outside, it has been characterized by $A-B$ period processes continuation and cuffs from hydrated SS between sand grains appearance. In addition, during period $B-C$ part of steam leaves mixture bulk, which did not have time to condense in capillaries, and sample temperature reaches $100{ }^{\circ} \mathrm{C}$. At the end of $B-C$ period practically no free water remains in sample. In addition, based on the fact that SS mass content in clad layer is commensurate with SWS mass and smaller in comparison with sample quartz sand mass, it can be assumed that SS hydration duration in clad layer is much shorter than vapor condensation on its surface duration. That is, resulting condensate is almost completely absorbed by SS mixture.

Period $C-D$. This period has been characterized by sample temperature increasing from 100 to $108^{\circ} \mathrm{C}$, hydrated SS foaming, and, accordingly, explosive sample weight decreasing at the end of this period. This is probably due to the fact that SS aqueous solutions with silicate modulus of 2.8-3.0 are mixture of colloidal hydrated structurally and chemically different $\mathrm{Na}_{2} \mathrm{SiO}_{3}$ aggregates. They contain chemically weakly bound hydration water, which removal occurs in these temperatures interval through foam structures in sample capillary channels formation and destruction.

Period $\boldsymbol{D}-\boldsymbol{E}$. This period has been characterized by sample weight invariability despite its temperature from 108 to $125-$ $127^{\circ} \mathrm{C}$ increasing.

Period $\boldsymbol{E}-\boldsymbol{F}$. This period duration in analyzed sample drying process is longest and takes $\sim 272 \mathrm{~s}$ (from 67 to $339 \mathrm{~s}$ ). Sample temperature during period E-F (Fig. 5) monotonically increases from $125-127$ to $138{ }^{\circ} \mathrm{C}$. Then sample heating rate increases sharply. This sample weight changing character indicates SS dehydration process in it completion. $E-F$ period relatively high temperature and long duration indicate that during this period hydrated water, which has strong chemical bond with SS, removes from sample.

According to Mokrousov G. M., Gorlenko N.P. (1988), Gapochka L. D., Gapochka M. G. (1994), Shipunov B. P., Selikov K.V. (2005), Masumi Yamashita, Chris Duffield, William A. (2003), Stas I.E., Bessonova A.P. (2010) and number of other researchers, electromagnetic field microwave effect on water and aqueous solutions changes a number of their physical and chemical properties, including viscosity, dielectric permeability, ion hydration degree, hydration heat, etc. Authors of above studies associate revealed regularities of microwave radiation aftereffects with water molecules in compounds arrangement ordering degree increasing. Since dehydration heat is equal in value and opposite in sign to dilution heat of solution, it can be assumed that $E-F$ period duration is due to sequence of hydrated SS molecules disintegration process development stages, as well as this process completeness. Certain discrepancy between noted periods with singular points beginning and finishing on temperature change dependence in time has been explained by thermal inertia of processes taking place in samples, due to samples
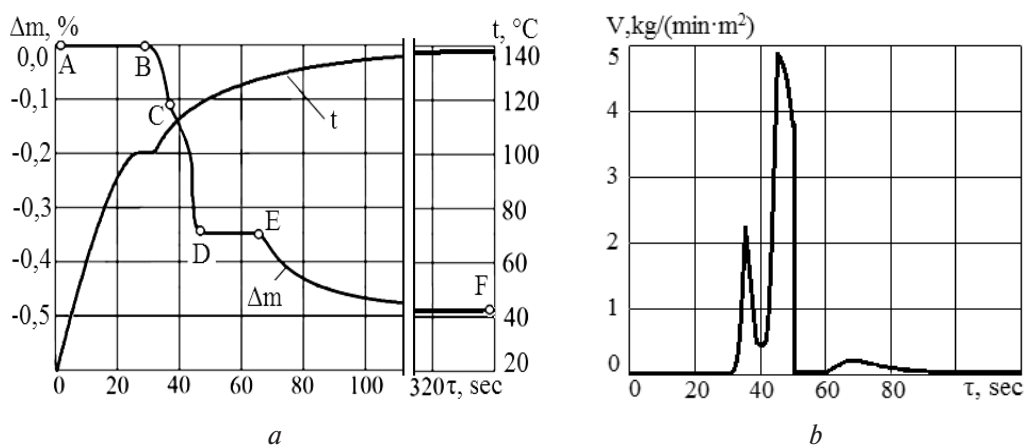

Fig. 5. Quartz sand cladded with $3 \%$ SSS (contained hydrated water less than $0.1 \%$ ) sample 5 relative mass changing vs. duration of its drying SWS under microwave radiation (a), water evaporation from sample 5 open surface kinetics changing rate (b) 
-mass, and controlling thermocouple in sample body hot junction location.

Based on water evaporation from sample (Fig. 5, b) rate changes kinetics and SSSM structuring completion temperature, and also from the fact that during microwave drying heat and moisture move from the most heated deep regions to the product colder surface layers, it is possible to assert that, in order to obtain casting mold or core in structuring their mixtures according to SMS processing, structuring mixture temperature should not be allowed to rise above $125^{\circ} \mathrm{C}$ (Fig. 5, a). Otherwise, released from mixture steam will condense on model-rod rigging colder surfaces and will dissolve dehydrated SS in product structured mixture surface layer, degrading its quality, which follows from images in Fig. 6 analysis.

To determine mixtures preliminary microwave treatment minimum duration for their subsequent structuring according to SMS-process, the average heating rate of quartz sand $200 \mathrm{~g}$ was determined during first 2 minutes during its treatment with microwave radiation at frequency of $2.45 \mathrm{GHz}$ and magnetron power of $900 \mathrm{~W}$. Results of average heating rates determination have been presented as histogram presentation in Fig. 7.

From data in Fig. 7 analysis follows that, prior to structuring by SMS process beginning, it is advisable to dry SSS-cladded quartz sand in microwave radiation field for at least $3 \mathrm{~min}$. Such technological operation in quartz sand cladding will make it possible to process the mixtures using SMS procedure for 2-4 minutes without risk of solidified product surface quality degradation due to mixture restructuring. Casting molds and cores production industrial practice shows, such preliminary drying will make it possible to manufacture prod-

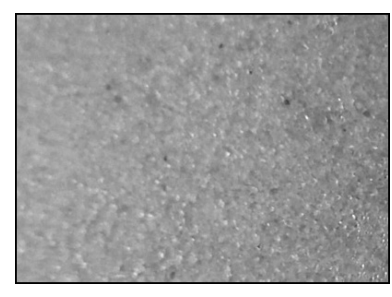

$a$

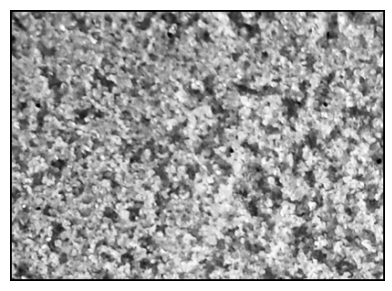

$b$
Fig. 6. Rod with mass of $400 \mathrm{~g}$ flat surface, made by the SMSprocess from quartz sand, cladded with $0.5 \%$ SSS and treated with $W C$ with mass of $1 \mathrm{~g}$ in microwave radiation for $150 s(a)$ and $400 s(b), \times 2$

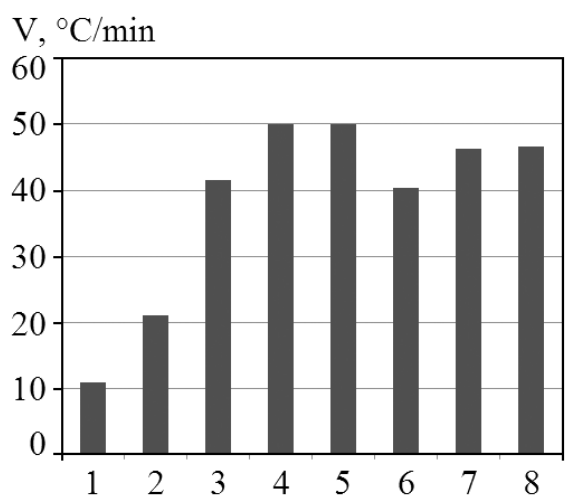

Fig. 7. Histogram of $200 \mathrm{~g}$ quartz sand heating for 2 minutes average rate when it is processed by microwave radiation:

1 - dry sand; 2 - dry sand and SWS; 3 - sand cladded with $0.5 \%$ SSS (water content in SS - 20\%); 4 - sand cladded with $1.5 \%$ SSS (water content in SS - 20\%); 5 - sand cladded with $2.5 \%$ SSS (water content in SS - 20\%); 6 - sand cladded with $0.5 \%$ SSS (water content in SS - 0\%); 7 - sand cladded with $1.5 \%$ SSS (water content in SS - 0\%); 8 - sand cladded with $2.5 \%$ SSS (water content in $S S-0 \%$ ) ucts from structured SSSM with stable and predictable level of their mechanical and technological properties.

SSSM maximum mass that can be structured with 1 gram of WC using SMS-process has been calculated from results of compiling its material balance.

Since SS contains two its forms $-\beta-\mathrm{Na}_{2} \mathrm{O} \cdot n \mathrm{SiO}_{2}$ and $\gamma-\mathrm{Na}_{2} \mathrm{O} \cdot n \mathrm{SiO}_{2}$ [20], then, apparently, this is the reason that water has been released from weighed samples with SSSM not only when their temperature rises to $100{ }^{\circ} \mathrm{C}$, but also in temperature range $100-108$ and $125-138^{\circ} \mathrm{C}$.

As it has been noted above, depending on cladding conditions at the time when steam-microwave treatment begins, cladding layer on quartz sand grains is partially or completely dehydrated SS, because only free water has been removed from SSS as drying in air result (at $100{ }^{\circ} \mathrm{C}$ )

$$
\begin{gathered}
\mathrm{Na}_{2} \mathrm{O} \cdot n \mathrm{SiO}_{2} \cdot m \mathrm{H}_{2} \mathrm{O} \rightleftarrows \\
\rightleftarrows \mathrm{Na}_{2} \mathrm{O} \cdot n \mathrm{SiO}_{2} \cdot \varphi \mathrm{H}_{2} \mathrm{O}+(m-\varphi) \mathrm{H}_{2} \mathrm{O}
\end{gathered}
$$

where $\varphi-$ mass fraction of hydrated water in SS

But all water removes during microwave drying

$$
\mathrm{Na}_{2} \mathrm{O} \cdot n \mathrm{SiO}_{2} \cdot m \mathrm{H}_{2} \mathrm{O} \rightleftarrows \mathrm{Na}_{2} \mathrm{O} \cdot n \mathrm{SiO}_{2}+m \mathrm{H}_{2} \mathrm{O}
$$

That is, characteristic $\varphi$ can take values from zero to value calculated by obtained from data processing results formula [18]

$$
\varphi=-0.0556 \cdot M_{\mathrm{SiO}_{2}}^{2}+0.2806 \cdot M_{\mathrm{SiO}_{2}}-0.1661,
$$

where $M_{\mathrm{SiO}_{2}}$ - is SSS silicate modulus in cladding layer.

At the same time, SS mass fraction in initial SSS with silicate modulus $M_{\mathrm{SiO}_{2}}=2.8-3.0$ will be

$$
z_{S S S}=0.01+1.075 \cdot \ln \left(\rho_{S S S}\right) \text {, }
$$

where $\rho_{S S S}-$ SSS specific density, $\mathrm{g} / \mathrm{cm}^{3}$.

In this case, water steam of $1 \mathrm{~g}$ using in SMS-process makes it possible to hydrate SS in quartz sand cladding layer with mass $m_{S S}$, g

$$
m_{S S}=\frac{1}{\varphi}-1 .
$$

Based on foregoing, SMS-process material balance can be represented by following formula

$$
\begin{gathered}
M_{C Q S}+M_{S}=M_{S Q S}+M_{S R} ; \\
M_{C Q S}=M_{Q S}+M_{S S}+M_{H W} ; \\
M_{S Q S}=M_{Q S}+M_{H S S},
\end{gathered}
$$

where $M_{C Q S}, M_{S Q S}, M_{Q S}, M_{S S}, M_{H W}, M_{S}, M_{H S S}, M_{S R}$ - mass of cladded quarts sand, mass of structured quarts sand, mass of pure quarts sand, mass of SS in cladding layer, mass of hydrated water in SS, mass of SWS used for sand structuring, mass of hydrated SS in cladding sand layer, mass of SWS not consumed (residual) for SS hydration, correspondently.

From material balance equation follows that, for example at $M_{H W}=M_{S R}=0$, taking into account (3-5), mass of cladded quartz sand structured according to SMS-process $\left(M_{S Q S}, \mathrm{~g}\right)$ can be calculated by formula

$$
\begin{aligned}
& \grave{I}_{C Q S}=\frac{m_{S S}}{z_{S S S}} \cdot \frac{1}{m_{S S C}}= \\
& =\frac{\left(\frac{1}{-0.0556 \cdot M_{\mathrm{SiO}_{2}}^{2}+0.2806 \cdot M_{\mathrm{SiO}_{2}}-0.1661}-1\right)}{0.01+1.075 \cdot \ln \left(\rho_{S S S}\right)} \cdot \frac{1}{m_{S S C}},
\end{aligned}
$$

where $m_{S S C}-$ SSS mass fraction consumed for quarts sand cladding.

Using formula (6), dependences $M_{S Q S}=f\left(m_{S S C}, M_{\mathrm{SiO}_{2}}\right.$, $\left.\rho_{S S S}\right)$ have been created. Initial data taken for calculations are given in Table. Calculation results are shown in Fig. 8. 

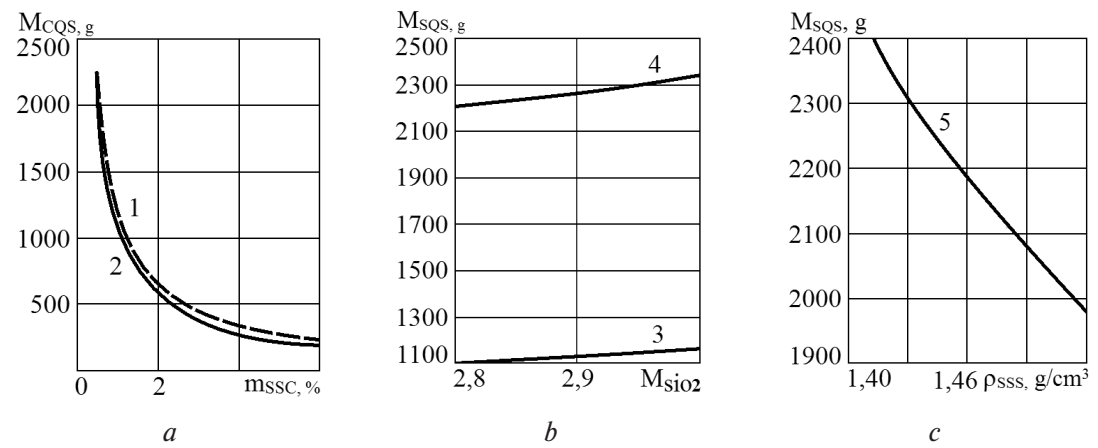

Fig. 8. Dependences $M_{S Q S}=f\left(m_{S S C}\right)(a), M_{S Q S}=f\left(M_{\mathrm{SiO}_{2}}\right)(b), M_{S Q S}=f\left(\rho_{S S S}\right)(c)$ :

$1-M_{\mathrm{SiO}_{2}}=2.9 ; \rho_{S S S}=1.44 \mathrm{~g} / \mathrm{cm}^{3} ; m_{S S C}=0-6 \%$ (experiment) $; 2-M_{\mathrm{SiO}_{2}}=2.9 ; \rho_{S S S}=1.44 \mathrm{~g} / \mathrm{cm}^{3} ; m_{S S C}=0-6 \% ; 3-M_{\mathrm{SiO}_{2}}=2.8-3.0$; $\rho_{S S S}=1.44 \mathrm{~g} / \mathrm{cm}^{3} ; m_{S S C}=1.0 \% ; 4-M_{\mathrm{SiO}_{2}}=2.8-3.0 ; \rho_{S S S}=1.44 \mathrm{~g} / \mathrm{cm}^{3} ; m_{S S C}=0.5 \% ; 5-M_{\mathrm{SiO}_{2}}=2.9 ; \rho_{S S S}=1.40-1.52 \mathrm{~g} / \mathrm{cm}^{3} ; m_{S S C}=0.5 \%$

From dependences in Fig. 8 course analysis it follows that SSS amount used for cladding and its specific gravity have most significant effect on cladded structured quartz sand. With SSS content used for cladding and its specific gravity increasing, structured sand mass decreases. At the same time, silicate modulus SSS increasing leads to mass of structured according to the SMS process sand insignificant increasing. That makes it possible not to take into account this parameter changing when technology for production of casting molds and cores developing, and to take the value $M_{\mathrm{SiO}_{2}}=2.9$ in calculations.

Based on the fact that, according to experimental studies results, structured by microwave radiation mixture mass changing in time can be described by square root law. It means, it is expedient to write formula (7) in the form

$$
\begin{gathered}
M_{C}=6 \frac{\left(\frac{1}{-0.0556 \cdot M_{\mathrm{SiO}_{2}}^{2}+0.2806 \cdot M_{\mathrm{SiO}_{2}}-0.1661}-1\right)}{0.01+1.075 \cdot \ln \left(\rho_{S S S}\right)} \times \\
\times \frac{\sqrt{\tau}}{m_{S S C}+0.125},
\end{gathered}
$$

where 6 - coefficient of proportionality; $\tau$ - duration of steam-microwave exposure to cladding sand, sec; $m_{S S C}-$ SSS content in quarts sand during its cladding process, $\%$ (weight).

From formula (8) and dependences in Fig. 8, $a$ analysis it follows that for casting molds and cores according to SMSprocess manufacturing, it is advisable to use quartz sand cladded with SSS of $0.5-2.5 \%$. This, with WC mass of $1 \mathrm{~g}$, will allow structuring from 450 to $2000 \mathrm{~g}$ of mixture during 4-8 minutes.

If the drying processes of studied in this work mixtures variants will be presented in digraphs form, then they will have the forms shown in Fig. 9. In Fig. 9 lines connecting digraphs

Table

Initial data taken for calculations using (7) and plotting dependencies in Fig. 8

\begin{tabular}{|c|c|c|c|l|}
\hline $\begin{array}{c}\text { Dependence } \\
\text { number in Fig. 8 }\end{array}$ & $M_{\mathrm{SiO}_{2}}$ & $\begin{array}{c}\rho_{\mathrm{SSS}}, \\
\mathrm{g} / \mathrm{cm}^{3}\end{array}$ & $\begin{array}{c}m_{S S C}, \% \\
\text { (weight) }\end{array}$ & Dependence \\
\hline 1 & 2.9 & 1.44 & $0-6$ & experimental \\
\hline 2 & 2.9 & 1.44 & $0-6$ & calculated \\
\hline 3 & $2.8-3.0$ & 1.44 & 1.0 & calculated \\
\hline 4 & $2.8-3.0$ & 1.44 & 0.5 & calculated \\
\hline 5 & 2.9 & $1.40-1.52$ & 0.5 & calculated \\
\hline
\end{tabular}

Note. Dependence 1 obtained with samples treated by 8 minutes duration SMS vertexes are periods that were highlighted on kinetic curves and are given in descriptions. Graphs vertexes $(A, B, C, D, G$, $L, E$, and $F$ ) are singular points in Figs. 2-5.

From Fig. 9 analysis it follows that, despite a certain similarity in studied mixtures compositions, not only their drying kinetics but also this process duration are different. In particular, sample 1 with water contain $0.5 \%$ (by weight) evenly distributed over sample volume drying duration was $\sim 118 \mathrm{~s}$. For sample 2, with the same water amount but with WC sample entering in SWS form, this drying time was $\sim 140 \mathrm{~s}$. For sample 3 (water content in sample was $2.8 \%$ ) drying time was $\sim 77 \mathrm{~s}$, drying time for sample 4 (water content in sample was $1.1 \%$ ) was $\sim 120 \mathrm{~s}$ and for sample 5 (water content in sample was $0.5 \%)-\sim 340 \mathrm{~s}$. That is, sand drying by microwave radiation for each specific mixture requires its own individual study to identify its regularities and peculiarities.

Conclusions. For the first time, drying rate kinetics has been investigated and description of mass over time changing process during cladded with sodium silicate solute quartz sand drying under microwave radiation action in limited amount of saturated water steam medium has been elaborated (structuring by SMS-process).

For the first time, on SMS-process material balance basis, analytical dependence has been developed. It's using allows, in first approximation, to calculate the maximum mass of sandsodium-silicate mixture, which can be structured by SMSprocess using sodium silicate solute and saturated water steam with mass of $1 \mathrm{~g}$.

According to investigation results has been demonstrated that during SMS process using water releases from structured mixture in three stages. First stage realizes at mixture temperature of $\sim 100{ }^{\circ} \mathrm{C}$, second stage - at $10-108{ }^{\circ} \mathrm{C}$, third stage - at $125-138{ }^{\circ} \mathrm{C}$. In this regard, maximum permissible heating temperature of structured sand-sodium-silicate mixture for SMS-process should be considered $125^{\circ} \mathrm{C}$. This temperature exceeding leads to hydrated water in steam form in mixture releasing. This steam can condense on model-rod rigging colder working surface and lead to created casting molds and rods surface quality decreasing.

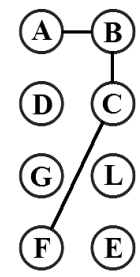

a

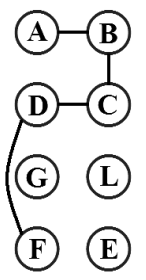

$b$

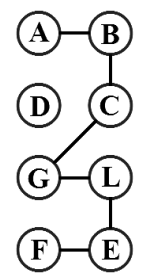

$c$

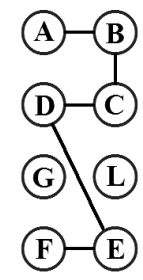

d
Fig. 9. Mixture drying kinetic curves digraphs:

$a$ - sand with water; $b$ - sand with WC; $c$ - sand with SSS; $d-$ SSS cladded sand with WC 
For casting molds and cores produced by SMS-process quality stabilization, it is recommended to dry cladded with sodium silicate solute quarts sand for at least 3 minutes in microwave radiation field before structuring.

\section{References.}

1. Yashina, S.A., \& Klyukova, T.D. (2018). Study on the mechanism of crumbling of self-hardening mixtures (review). VIAM Proceedings, 6(66), 110-118. ISSN 2307-6046.

2. Solonenko, L., Prokopovich, I., Repyakh, S., Sukhoi, K., \& Dmytrenko, D. (2019). System analysis of modern areas of increasing environmental and sanitary hygienic safety of using cold hardening mixtures in foundry. Odessa Polytechnic University, Proceedings, (57), 90-98. ISSN 2076-2429.

3. Shnaider, S. E., \& Varnikov, Yu. A. (2018). Some features of the kinetics of liquid dispersed products in the foamed state. Science without borders, 10(27), 83-86. ISSN 2500-1191.

4. Alshanski, A., \& Kotow, A. (2020). Head and mass transfer during convective drying of thin flat wet materials. Vestnik of Vitebsk state technological university, 1(38), 79-90. https://doi. org/10.24411/2079-7958-2020-13808.

5. Volkhonov, M., Jabbarov, I., Soldatov, V., \& Smirnov, I. (2018). Development of the method of exposure control of grain drying in high-temperature dryers. Eastern-European Journal of Enterprise Technologies, 3(93), 22-29. https://doi. org/10.15587/1729-4061.2018.133607.

6. Alekseev, G.V., Egorova, O.A., Leeuw, A. G., \& Derkanosova, A. A. (2017). Specifics of powdered food products' drying in a fluidized. Bulletin of the South Ural State University. Series Food and Biotechnology, 4, 34-40. ISSN 23102748.

7. Kodylev, A. V., Lozinov, A. N., \& Sadykov, R. A. (2016). Kinetics of convective drying of bulk and dispersed building materials in a drying unit with heat carrier recovery. News of KSUAE, 4(38), 308-313. ISSN 2073-1523.

8. Efremov, G. I., \& Geller, J.A. (2018). Modeling of drying materials for building ceramics. Bulletin of the Moscow Information Technology University - Moscow Institute of Architecture and Civil Engineering, 1, 14-19. ISSN 2619-046X.

9. Antipov, S. T., Toroptsev, V.V., Martekha, A. N., Berestovoy, A.A., \& Yurova, I. S. (2019). Kinetics of the drying process of fermented wheat raw materials in a vibratory boiling layer. Proceedings of VSUET, 81(4), 17-21. ISSN 2226-910X.

10. Gavrilova, N.D., \& Malyshkina, I.A. (2018). The influence of changes in the structure of hydrogen bonds of water on the electrophysical properties of matrix-water systems in stepwise heating. Moscow University Physics Bulletin, 6, 74-80. ISSN 0579-9392.

11. Salomatov, V. V., Karelin, V.A., \& Salomatov, V. V. (2019). Electromagnetic drying of wet materials with microvave low penetration depth in condition of heat removal by radiation and convection. I. Warm up phase. Bulletin of the Tomsk Polytechnic University. Geo Assets Engineering, 330(12), 119-125. https://doi.org/10.18799/24731830/2019/12/2408.

12. Kramarenko, V.V., Nikitenkov, A. N., \& Molokov, V. Yu. (2017). Applicability of microwave method for determining soil moisture. Bulletin of the Tomsk Polytechnic University. Geo Assets Engineering, 328(11), 60-74. ISSN 2500-1019.

13. Solonenko, L.I., Bilyi, O.P., Repiakh, S. I., Kimstach, T.V., \& Uzlov, K. I. (2020). Heating rate of granular inorganic materials by microwave radiation. Naukovyi Visnyk Natsionalnoho Hirnychoho Universytetu, (2), 37-41. https:// doi.org/10.33271/nvngu/2020-2/037.

14. Klimenko,V. G. (n.d.). (2017). The role of $\mathrm{Na}^{+}, \mathrm{K}^{+}, \mathrm{Ca}^{2+}$, $\mathrm{NH}^{4+}$ sulfates-based double salts in derivation of anhydrite binders. Vestnik BGTU im. V. G. Šuhova, 12, 119-125. https:// doi.org/10.12737/article 5a27cb84ae0049.79523605.

15. Illarionov, I. E., Strelnikov, I.A., Gartfelder, V.A., Korolev, A. V., \& Gilmashina, T. R. (2018). Development and application of metal phosphate binders for the production of molding, core and heat-insulating mixtures and coatings.
Theory and technology of metallurgical production, 4(27), 4-10. ISSN 2311-5378.

16. Fedotov, A.A., Vakhnina, T. N., Titunin, A.A., \& Sviridov, A. V. (2020). Study of the influence of stabilizers on the properties of carbamide formaldehyde binder and FC plywood. Forestry journal, 1, 136-143. https://doi.org/10.3422/ issn.2222-7962/2020.1/14.

17. Krutilin, A.N., Guminski, Yu.Yu., \& Rusevich, O.A. (2018). Improving the efficiency of using liquid-glass mixtures. Part 4. Combined strengthening. Foundry production and metallurgy, 4(93), 38-44. https://doi.org/10.21122/1638-60652018-4-38-44.

18. Repyakh, S. I., Solonenko, L. I., Biliy, O. P., Usenko, R. V., \& Uzlov, K. I. (2019). The power and structure of the components in food-and-business formal sums. Theory and practice, 1, 81-92. ISSN 1028-2335.

19. Grimzin, I., Ponomarenko, O., Marynenko, D., Yevtushenko, N., \& Berlizeva, T. (2019). The technological process of obtaining sand-plaster molds for complex thin-walled aluminum casting. Advanced Manufacturing Processes: Selected Papers from the Grabchenko's international conference on advanced manufacturing process, (pp. 405-414). InterPartner 2019, LNME. https://doi.org/10.1007/978-3-030-40724-7.

20. Solonenko, L. I., Repyakh, S. I., \& Uzlov, K. I. (2019). Kinetics of the structure of the food-borne sums of steam-microchilles solidification. Theory and practice, 4, 44-56. ISSN $1028-2335$

\section{Кінетика сушіння кварцового піску та його сумішей мікрохвильовим випромінюванням}

\section{Л. І. Солоненко ${ }^{1}$, С. I. Реп'ях ${ }^{2}$, К. I. Узлов ${ }^{2}$, І. Мамузич, Т. В. Кімстач ${ }^{2}$ О. П. Білий ${ }^{2}$}

1 - Одеський національний політехнічний університет, м. Одеса, Україна

2 - Національна металургійна академія України, м. Дніпро, Україна, e-mail: 123rs@ua.fm

3 - Загребський університет, Хорватське металургійне товариство, м. Загреб, Республіка Хорватія

Мета. Дослідження кінетики та встановлення механізму сушіння мікрохвильовим випромінюванням кварцового піску та його сумішей з силікатом натрію в середовищі обмеженої кількості водяної пари.

Методика. У роботі використовували дистильовану воду, рідке скло та кварцовий пісок. Дослідження проводили на наважках піску масою 200 г. Сушіння та структурування сумішей проводили мікрохвильовим випромінювання потужністю 700 Вт із частотою 2,45 ГГц на повітрі та у середовищі насиченої водяної пари масою 1 г. Точність вимірювання температури $-1{ }^{\circ} \mathrm{C}$, маси $-0,02$ г. Кінетика сушіння, що була прийнята в роботі - залежність зміни маси навішення та швидкості випаровування 3 нього вологи від тривалості сушіння. Залежності будували за результатами відеореєстрації та оцифровки даних відповідних хроно-гравиметричних вимірювань. Вимір змін температури наважок сумішей при нагріванні мікрохвильовим випромінюванням проводили з інтервалом 15-60 с. Середню швидкість нагріву наважок визначали розрахунковим шляхом за результатами визначення зміни їх температури за перші 2 хвилини нагрівання мікрохвильовим випромінюванням.

Результати. Уперше досліджена кінетика та описано механізм сушіння мікрохвильовим випромінюванням кварцового піску та його сумішей з силікатом натрію в середовищі обмеженої кількості водяної (структурованого за ПМЗ-процесом). Уперше на основі матеріального балансу ПМЗ-процесу розроблена аналітична залежність, використання якої дозволяє розрахувати макси- 
мальну масу піщано-рідкоскляної суміші, структурованої за ПМЗ-процесом, при використанні для плакування кварцового піску натрієвого рідкого скла (силікатний модуль 2,8-3,0), та 1 г насиченої водяної пари для структурування суміші. Встановлено, що при структуруванні сумішей по ПМЗ-процесу, виділення з них води проходить у три етапи - при $\sim 100,100-108$ і при $125-138{ }^{\circ} \mathrm{C}$. Рекомендована максимально припустима температура нагрівання піщано-рідкоскляної суміші під час структурування за ПМЗ-процесом складає $\sim 125^{\circ} \mathrm{C}$. Перевищення зазначеної температури призводить до виділення гідратної води в суміші у вигляді пари та їі конденсації на холоднішій робочій поверхні модельно-стрижневого оснащення. Виниклий конденсат призводить до переструктуризації суміші в місцях іiі контакту з оснащенням i, відповідно, різкого погіршення якості виготовлених ливарних форм і стрижнів. Для стабілізації якості при виготовленні ливарних форм і стрижнів рекомендовано до початку структурування за ПМЗ-процесом плакований натрієвим рідким склом кварцовий пісок попередньо просушити в полі мікрохвильового випромінювання протягом не менше 3 хвилин.

Наукова новизна. Уперше отримані дані про кінетику сушіння та описано механізм сушіння мікрохвильовим випромінюванням кварцового піску та його сумішей 3 силікатом натрію в середовищі обмеженої кількості водяної пари, встановлені закономірності впливу ряду основних параметрів ПМЗ-процесу на масу структурованого кварцового піску.

Практична значимість. Результати досліджень будуть корисні в частині розширення уявлень щодо процесів, які супроводжують сушку зернистих матеріалів, а також при розробці технологій та обладнання, призначених для сушіння й структурування дрібнозернистих діелектричних матеріалів і їх сумішей, створення нових капілярнопористих середовищ і т.п. під впливом мікрохвильового випромінювання.

Ключові слова: кінетика сушіння, пісок, силікат натрію, пара, структурування, мікрохвильове випромінювання

\section{Кинетика сушки кварцевого песка и его смесей микроволновым излучением}

\author{
Л. И. Солоненко ${ }^{1}$, С. И. Репях ${ }^{2}$, К. И. Узлов ${ }^{2}$ \\ И. Мамузич, Т. В. Кимстач ${ }^{2}$, А. П. Белый
}

1 - Одесский национальный политехнический университет, г. Одесса, Украина

2 - Национальная металлургическая академия Украины, г. Днепр, Украина, e-mail: 123rs@ua.fm

3 - Загребский университет, Хорватское металлургическое общество, г. Загреб, Республика Хорватия

Цель. Исследование кинетики и установление механизма сушки микроволновым излучением кварцевого песка и его смесей с силикатом натрия в среде ограниченного количества водяного пара.

Методика. В работе использовали дистиллированную воду, жидкое стекло и кварцевый песок. Исследования проводились на навесках песка массой 200 г. Сушку и структурирование смесей проводили микроволновым излучением мощностью 700 Вт с частотой 2,45 ГГц на воздухе и в среде насыщенного водяного пара массой 1 г. Точность измерения температуры $-1{ }^{\circ} \mathrm{C}$, массы $-0,02$ г. Кинетика сушки, принятая в работе - зависимость изменения массы навески и скорости испарения из неё влаги от продолжительности сушки. Зависимости строили по результатам видеорегистрации и оцифровки данных соответствующих хроно-гравиметрических измерений. Измерение изменений температуры навесок смесей при нагреве микроволновым излучением проводили с интервалом 15-60 с. Среднюю скорость нагрева навесок определяли расчетным путем по результатам определения изменения их температуры за первые 2 минуты нагрева микроволновым излучением.

Результаты. Впервые исследована кинетика и описан механизм сушки микроволновым излучением кварцевого песка и его смесей с силикатом натрия в среде ограниченного количества водяного (структурированного по ПМО-процессу). Впервые на основе материального баланса ПМО-процесса разработана аналитическая зависимость, использование которой позволяет рассчитать максимальную массу песчано-жидкостекольной смеси, структурированной по ПМО-процессу, при использовании для плакирования кварцевого песка натриевого жидкого стекла (силикатный модуль $2,8-3,0$ ) и 1 г насыщенного водяного пара для структурирования смеси. Установлено, что при структурировании смесей по ПМО-процессу выделение из них воды проходит в три этапа - при 100, $100-108$ и при $125-138^{\circ} \mathrm{C}$. Рекомендуемая максимально допустимая температура нагрева песчано-жидкостекольной смеси при структурировании по ПМО-процессу составляет $\sim 125^{\circ} \mathrm{C}$. Превышение указанной температуры приводит к выделению гидратной воды в смеси в виде пара и его конденсации на более холодной рабочей поверхности модельно-стержневой оснастки. Возникший конденсат приводит к переструктуризации смеси в местах ее контакта с оснасткой и, соответственно, резкому ухудшению качества изготовленных литейных форм и стержней. Для стабилизации качества при изготовлении литейных форм и стержней рекомендуется до начала структурирования по ПМО-процессу плакированный натриевым жидким стеклом кварцевый песок предварительно просушить в поле микроволнового излучения в течение не менее 3 минут.

Научная новизна. Впервые получены данные о кинетике сушки и описан механизм сушки микроволновым излучением кварцевого песка и его смесей с силикатом натрия в среде ограниченного количества водяного пара, установлены закономерности влияния ряда основных параметров ПМО-процесса на массу структурированного кварцевого песка.

Практическая значимость. Результаты исследований будут полезны в части расширения представлений о процессах, которые сопровождают сушку зернистых материалов, а также при разработке технологий и оборудования, предназначенных для сушки и структурирования мелкозернистых диэлектрических материалов и их смесей, создания новых капиллярно-пористых сред и т.п. под влиянием микроволнового излучения.

Ключевые слова: кинетика сушки, песок, силикат натрия, пар, структурирование, микроволновое излучение

Recommended for publication by $V$. Yu. Seliverstov, Doctor of Technical Sciences. The manuscript was submitted 14.07.20. 